\title{
SIGN LANGUAGE LEXICOGRAPHY: A CASE STUDY OF AN ONLINE DICTIONARY
}

\section{Lucia VLÁŠKOVÁ}

Support Centre for Students with Special Needs (Teiresiás), Masaryk University

\section{Hana STRACHOŇOVÁ}

Faculty of Arts, Masaryk University

Vlášková, L., Strachoňová, H. (2021): Sign language lexicography: a case study of an online dictionary. Slovenščina 2.o, 9(1): 90-122.

\section{DOI: https://doi.org/10.4312/slo2.0.2021.1.90-122}

As a growing field of study within sign language linguistics, sign language lexicography faces many challenges that have already been answered for audio-oral language material. In this paper, we present some of these challenges and methods developed to help navigate the complex lexical classification field. The described methods and strategies are implemented in the first Czech sign language (ČZJ) online dictionary, a part of the platform Dictio, developed at Masaryk University in Brno. We cover the topic of lemmatisation and how to decide what constitutes a lexeme in sign language. We introduce four types of expressions that qualify for a dictionary entry: a simple lexeme, a compound, a derivative, and a set phrase. We address the question of the place of classifier constructions and shape and size specifiers in a dictionary, given their peculiar semantic status. We maintain the standard classification of classifiers (whole entity and holding classifiers) and size and shape specifiers (SASSes; static and tracing specifiers). We provide arguments for separating the category of specifiers from the category of classifiers. We discuss the proper treatment of mouthings and mouth gestures concerning citation forms, derivation and translation. We show why it is difficult in sign language to distinguish synonyms from variants and how our proposed phonological criteria can help. We explain how to construct a semantic definition in a sign language and what is the solution for multiple meanings of one form. We offer simple guidelines for forming proper examples of use in a sign language. And finally, we briefly comment on the process of the translation between sign and spoken languages. We conclude the paper with a summary of roles that Dictio plays in the ČZJ-signing community.

Keywords: sign language, lexicography, dictionary, methodology 
Dictio is a multilingual online dictionary that includes multiple languages, both sign and spoken. This ongoing project is being realised at Masaryk University in Brno, Czech Republic. Currently, it includes entries for the following languages (ordered by the approximate number of entries): Czech (120 thousand), Czech Sign Language - ČZJ (13 thousand), Slovak Sign Language ( 5 thousand), Slovak (5,5 thousand), English (5,5 thousand), Austrian German (5,5 thousand), Austrian Sign Language (3,5 thousand), International Sign (170), and American Sign Language (120). Only a section of the entries has been published, the rest is still the subject of editing work of multiple working groups, including international teams of Deaf university employees. At the time of writing (January 2021), the number of the sign language published entries are as follows: Czech Sign Language - 3075, Slovak Sign Language - 35, International Sign - 12, American Sign Language - 20.

The field of sign language lexicography has been growing rapidly. Considering Stokoe's (1960/2005) description of the lexical units in American Sign Language as the pioneering work which respects the established linguistic principles, sixty years later, we make use of systematised databases for a whole range of sign languages in the form of printed books or offline and online databases (see the overview in McKee and Vale, 2017 or Fenlon et al., 2015). Since the seminal work of Johnston and Schembri (1999) on lemmatisation of the Australian Sign Language corpus (and closely connected Australian Sign Language lexical database), several researchers have published their experiences in the form of applicable universal guidelines for the lexicographic work on any sign language. Recently, many topics concerning mainly the electronic lexical databases have been addressed in the literature: e.g., history and options of the sign description and search (Zwitserlood, 2010, focusing on dictionaries of Dutch Sign Language), lexicographic specifics of sign languages compared to spoken languages (Kristoffersen and Troelsgård, 2012, with particular focus on the lexical database of Danish Sign Language), phonological and morphological variation in the process of lemmatisation (Fenlon et al., 2015, on the material of British Sign Language), and others. At the beginning (around 2009), our project was inspired mainly by the work of Johnston and Schembri (1999) and online public dictionaries of Italian Sign Language (e-LIS) and French Sign Language (Elix). 
The choice of our sources of inspiration arose from the ambition of our project: to create an up-to-date sign language dictionary comparable to standard spoken language dictionaries. Firstly, we were interested in providing linguistic metadata like the sign's lexical category, its region of use, or its grammatical modifications (hence Johnston and Schembri's work). Secondly, we aimed to create semantic definitions and examples of use for each meaning directly in ČZJ. Even today, that is not obvious for a sign language dictionary. We can still find several sign language dictionaries that explain the meaning of a sign using the surrounding spoken language (in some cases, that also applies to the examples of use). From this perspective, we consider the editors of e-LIS and Elix to be pioneers who we wanted to emulate.

In the absence of a representative ČZJ corpus, the linguistic material for the ČZJ part of the dictionary comes from two primary sources: previously published dictionaries and ČZJ informants. Dictio has the ambition to collect all the published ČZJ dictionaries and make them available in one database. That covers printed books (mainly Potměšil, 2002, 2004, 2004a), CDs (Langer, 2005, 2005a, 2008, a.o.), and other individual projects (e.g., diploma theses focusing on specific semantic fields, teaching materials for ČZJ commercial or university courses). The collection of previously published material is being edited, annotated and completed by a team of native signers of ČZJ, ČZJ interpreters and linguists. A substantial part of the team's work is to discuss synonyms and variants for the published entries. This way, plenty of new material is being elicited for the Dictio database.

In this paper, we introduce selected topics from sign language lexicography. The idea is to describe some linguistic issues we have encountered while working on the ČZJ part of the dictionary and propose guidelines applicable to the field of sign language lexicography in general. ČZJ was the first language introduced into the dictionary. Creating the linguistic methodology has been especially challenging since the original vision of the entire project was to construct the first monolingual dictionary, in this case, a dictionary of ČZJ, where the meaning and the use of the signs are explained and illustrated solely in ČZJ. As Dictio was becoming multilingual, links to the parts containing other languages (translations) were added to the entries. That is why proper semantic definitions were crucial, which will also be discussed below. 


\section{LEMMATISATION AND TYPES OF DICTIONARY ENTRIES}

The most fundamental question when compiling a sign language dictionary is what kind of signs to include, i.e., what constitutes an entry in a dictionary. The following strategy has been developed to answer this question: first, we take all the possible kinds of signs occurring in natural speech (lexeme, deixis, description, compound, collocation, set phrase) and divide them into two groups according to their complexity: the ones that do not consist of multiple semantic units (lexeme, deixis) and the ones that do (description, collocation, compound, set phrase). The first group is illustrated with the signs BLACK and IX-a, the latter with DEFECT, FEBRUARY, VETERINARY and $25^{\mathrm{TH}} \cdot{ }^{1} \mathrm{DE}-$ FECT contains two lexical roots: FAULT and BREAK-DOWN. In FEBRUARY, a native signer can distinguish the roots of MASK and DANCE. VETERINARY is formed by a sequence of DOCTOR, FOCUS and ANIMAL. And finally, $25^{\mathrm{TH}}$ simply linearizes the numerals 20 and $5^{\mathrm{TH}}$. Among the group of simple expressions, we set aside the expression, the meaning of which changes according to the referent (deixis: IX-a) and select the expression with a conventionally established meaning (lexeme: BLACK). We single out the expressions with a non-compositional meaning from the group of complex expressions, i.e., the set phrase (DEFECT) and the compound (FEBRUARY). Similarly to the spoken language dictionaries, collocations $\left(25^{\mathrm{TH}}\right)$ and descriptions (VETERINARY) are not listed as dictionary entries. Language users combine them regularly using the established lexicon and grammar of the language. However, they found their place in the example section of the entry (see Section 7 of this paper).

The above-described strategy leaves us with only three candidates for a dictionary entry: a traditional lexeme (BLACK), a compound (FEBRUARY), and a set phrase (DEFECT), with conventionally established meanings. In Dictio, however, we make another distinction, i.e. we divide the group of traditional lexemes into a group of motivated/derived signs and a group of simple unmotivated signs. Therefore, we classify signs into four types of entries: simple signs, compounds, set phrases, and derivatives. Let us briefly comment on each type.

1 We use the gloss IX-a for an index pointing at a location $a$, as is common. A possible translation could be that. 
Simple signs are monomorphemic. In our diagnostics of a sign language morpheme (namely the root), we follow Sandler (2006) and her two criteria that must be met to classify the sign as monomorphemic: The Selected Finger Constraint and The Place Constraint. The Selected Finger Constraint (originally in Mandel, 1981; revisited by Sandler, 1989) says that only one set of fingers can be selected within a morpheme. Note that this requirement allows the internal movement of the fingers. ${ }^{2}$ Compare a monomorphemic sign LAMP which displays one selection of fingers (changing their position from closed to open) with the sign RECOMMEND, which contains two selection of fingers (one open finger in the initial position, all open fingers in the final position), and is thus analysed as multimorphemic (a compound).

The second criterion we consider is The Place Constraint (originally in Battison, 1978; revisited by Sandler, 1989). It states that a morpheme can contain only one place of articulation. There are four main places of articulation: the neutral space, the head, the trunk, and the non-dominant hand. A movement from one location to another within the same main area is not considered a change of the place. The logic of the constraint is applied as follows: the sign POST-OFFICE is multimorphemic (a compound) because the dominant hand moves from the head to the non-dominant hand. In contrast, the sign NAME is compliant with the constraint: the hand moves from the contralateral to the ipsilateral side of the forehead. Both locations are a part of just one place of articulation (the head), and that is why the sign is classified as monomorphemic (simple).

Compounds are morphologically complex signs that originated by merging two independent signs, i.e., two free morphemes. From the semantic point of view, compounds are not bound to introduce a new meaning, as seen in the ČZJ example of SUN^ ${ }^{\wedge}$ GLASSES 'sunglasses'. Nevertheless, it is possible, e.g., FLOWER`SPRING 'May' (Mladová, 2009). It is often difficult to distinguish compounds from set phrases, another type of entries in our dictionary. Set phrases also consist of two (or more) free morphemes, but their meaning is not compositional, e.g., in ČZJ sign UNIVERSITY, which consists of HIGH

2 Selected fingers are fingers that constitute the handshape. The fingers may be open (like in SUGAR with selected thumb and index finger) or closed (like in POST-OFFICE with all the fingers selected). The internal movement is defined as a change of the orientation of the dominant hand or a change of the position of its fingers (open/closed). 
and SCHOOL. However, in the case of compounds it is not the semantic shift that classifies them as such but the phonological reduction/assimilation, as defined by Zeshan (2004): the first sign is shortened and loses stress, any repetitions and internal movements are deleted, handshape and location can be assimilated, and the passive hand can function as a place of articulation. ${ }^{3}$ On the other hand, no such modification can be found in set phrases, where all constituting signs are fully realised.

The last type represented in our dictionary are the derivatives, defined as forms that have been derived from their respective motivating signs through adding or changing a non-manual component, which we will discuss in more detail in Section 4. Typically, this process occurs while deriving a technical or more specific term from a general vocabulary sign. Sandler (2006) affirms that mouthing is of a significant lexical role. Take an example from ČZJ where SACCHARIDE is derived from SUGAR. These two signs have the same manual component but differ in mouthing. SUGAR is standardly articulated without mouthing, and SACCHARIDE contains the mouthing of the Czech word for saccharide. ${ }^{4}$

Another critical question is the choice of a citation form (headword) of each entry. Following Johnston and Schembri (1999), only the unmodified signs in their basic forms are present in the lexicon (and, therefore, the dictionary), inflexion and modification are part of the grammar. Modification can take several forms, as defined in Zeshan (2002, 2004): (i) modified movement expresses the change in aspect, number, degree or directionality (verbal inflexion encoding the subject and/or the object of the given verb like ${ }_{1} R_{E T U R N}$ 'I return (sth) to you' vs ${ }_{2}$ RETURN $_{1}$ 'you return (sth) to me'; or intensification like in RAIN vs RAIN-A-LOT); (ii) modified handshape signals classifier constructions and numeral incorporation (e.g., HOUR can incorporate numerals up to 10, as seen in FOUR-HOUR with an incorporated numeral four); (iii) modified facial expressions distinguish between clause types, such as indicative, interrogative, negative (e.g., LIKE and NOT-LIKE) and others. In Dictio,

3 At least one reduction/assimilation pattern must be present to classify the item as a compound.

4 More precisely, the sign for SUGAR may be accompanied by the mouthing of the Czech word for sugar, but the sign for SACCHARIDE must be articulated with the mouthing of the Czech word for saccharide. 
the information whether a sign can incorporate numerals, (classifiers for) subject and/or object, and other modifiers is given in the grammatical part of the dictionary entry. The lexeme is presented in its basic form, i.e. singular, non-modified and non-intensified sign, such as the above-mentioned HOUR. The basic form for signs that incorporate a numeral is the one with incorporated ONE. For directional signs, it is the form directed from the speaker to the addressee.

However, there are exceptional cases when the dictionary also covers other than basic forms of signs. Such instances include deixis with fixed hand position, e.g., the pronouns I and MY that are always signed facing the speaker, and, correspondingly, YOU and YOUR, always facing the addressee. Furthermore, lexicalised forms of different types have their place in the dictionary, e.g., lexicalised deixis. Take the ČZJ verb HEAR, which is realised by pointing to the speaker's ear with a crooked index finger. As deixis, the pointing sign would be interpreted as that (consequently, as ear). The lexicalisation process is observed at two levels: formal and semantic. The formal change consists in the movement modification (the hand moves from the ear). During the semantic shift, the meaning no longer corresponds to the object that is being pointed at. It shifted to the activity realized by the object. Other forms of lexicalisation include lexicalised classifier constructions, which we will discuss in the following section, or lexicalised fingerspelling, as the sign for engineer - I-N-G, fingerspelled with the letters of the ČZJ alphabet.

\section{CLASSIFIERS, SPECIFIERS AND LEXICALISED CONSTRUCTIONS}

Classifiers have repeatedly proven to be an exciting research topic among sign linguists. This section will focus on different classifiers, a closely related group of specifiers, and the ways of properly incorporating them into a dictionary.

Sign language classifiers are considered a special kind of morphemes, the meaning of which is not precisely specified. They represent nominals and denote relevant properties of the respective entities via different configurations of the manual articulator (Zwitserlood, 2012), specify shapes and dimensions of objects, and denote spatial relations and motion events (Sandler and Lillo-Martin, 2006). Such entities are then categorised according to their 
properties into groups, e.g., flat objects, long and thin objects, two-legged beings, etc. Classifiers have been attested in all known sign languages (Sandler and Lillo-Martin, 2006), thus constituting a stable class with common general attributes, although the inventory of the particular classifiers differs from one language to another (Zwitserlood, 2012).

The categorisation of different types of classifiers has been a subject of much discussion. Earlier literature (Supalla, 1986, a.o.) had divided them into multiple classes based on various characteristics (e.g., semantics, shape, function, animacy) before currently stabilizing on two main types: whole entity classifiers and handling classifiers, based more on their function in grammar rather than their semantic properties (Zwitserlood, 2012). This internal classification is used in Dictio as well, and we will briefly comment on each group in the following passage.

Whole entity classifiers denote their referents in their entirety. They are more abstract and 'refer to general semantic classes rather than to visually perceived physical properties' (Sandler and Lillo-Martin, 2006, p. 77). However, various classifiers can denote a single entity, each highlighting a different relevant aspect (Zwitserlood, 2012).

An example from ČZJ is the representation of a person in a hypothetical story describing various activities of the person. We can talk, e.g., about a teacher who at first comes in the classroom (using the classifier for a person; CL:person), and later sits down at the table (represented by the classifier for two legs; CL:two-legs). The referent remains the same (the teacher), while two different classifiers describe his/her actions. Whole entity classifiers play a syntactic role of a subject. They combine with intransitive verbs that express the movement or localization of the referent in space.

On the other hand, handling classifiers utilize iconicity on a larger scale; they indicate the entity's shape as it is being held or manipulated with. The manual articulator represents itself - a hand holding the entity. This strategy gives the speaker much more room to choose among different classifiers according to the situation in the actual world (Zwitserlood, 2012). Handling classifiers play a syntactic role of an object. They combine with transitive verbs that express the manipulation with the object in space (e.g., CL:round-object). 
From the morphological point of view, classifiers are bound morphemes. They must occur jointly with other expressions within so-called classifier constructions, within which they are incorporated mostly into classifier verbs, i.e., verbs denoting movement, position or existence of a referent in space or some kind of manipulation (Zwitserlood, 2012). Classifier constructions represent a very productive strategy in sign languages, and this unstable semantic and morphological status prevents them from being documented in a dictionary.

However, classifiers outside of classifier constructions (so-called classifier handshapes) can be documented. In our dictionary, classifier handshapes are registered in individual lexical entries if there is a (relatively neutral) stabilised representative form with (at least roughly) delimited meaning (e.g., via extensional definition by listing possible referents, see Section 5 ).

An example of such a classifier handshape from ČZJ is one of the most common, basic handshapes - an open palm with all fingers stretched out (CL:flat-object). In the grammar part of this entry, the sign is categorised into its classifier group, whole entity classifiers. Two meanings are listed: a denotation of either flat objects or four-tired vehicles. Consequently, definitions and examples of use are listed for each meaning separately; in this case a sentence where the classifier denotes a book in the former, and a car in the latter meaning.

Let us turn now to the lexical category of the size and shape specifiers (SASSes). Like classifiers, SASSes are highly iconic and describe the visual characteristics of entities. While some researchers understand the SASSes as a classifier type, we follow Zwitserlood (2012) by placing them apart. Without doubt, there are some morphological, syntactic and semantic properties shared by the domain of classifiers and SASSes, e.g., some common handshapes, a postposition to the noun and their interpretation fully dependent on the preceding noun. However, we argue for an independent lexical category of SASSes building on the following differences: firstly, SASSes carry out different syntactic functions than classifiers. Typically, they behave like modifiers (noted, e.g., in Sandler and Lillo-Martin 2006, p. 77). They specify the preceding noun's properties, unlike classifiers, which substitute the noun and have a role 
resembling more that of pronouns. ${ }^{5}$ From the morphological point of view, SASSes are independent, meaning that they are not incorporated into any verbal predicates like classifiers are. The movement in classifier constructions is always a parameter of the verb. The classifier is just the handshape. On the other hand, the movement present during the articulation of the specifier represents a proper phonological parameter of the specifier, alongside, of course, its handshape. Following the standard classification, we distinguish two types of SASSes in Dictio: static and tracing SASSes (e.g., Quer et al., 2019). Static SASSes do not contain the parameter of movement. Their interpretation is based on the handshape (single-handed signs; e.g., SASS:dot) or the hands' respective positions (two-handed signs; e.g., SASS:size). On the other hand, tracing SASSes do contain movement, which is crucial for their interpretation. A good example is SASS:rectangle. The resulting meaning is composed of the handshape (the distance between the open fingers), the hands' position, and the imaginary trace that the fingers leave behind while moving. We can also find several examples in which the interpretation derives merely from the movement alone (SASS:circle, a.o.).

For a specifier to be registered as a separate entry in our dictionary, the same criteria apply as those for classifiers; a stabilised representative form with a roughly delimited meaning has to be attested. That is the case of SASS:three-rows that covers two general meanings: three scratches or three lines.

As we mentioned above, there are cases of handshapes common both to the domain of classifiers and SASSes alike. Among the numerous examples in ČZJ, we note the following two: CL:flat-object is used, as was mentioned before, as a whole entity classifier for flat objects or motorized vehicles with four wheels in combination with verbs of movement and localization. The same handshape can also be used in the SASS describing an object's surface or a border of an area. Similarly, CL:thin-object is a handling classifier that represents a thin held object. The same handshape is used as a parameter of a SASS describing a long cylindrical shape of an object. Since Dictio organizes the entries on the basis of the formal criteria of the signs, a shared handshape between the classifiers and the SASSes constitutes one single entry. Take for

5 Although, Zwitserlood (2012) also notes the nominal and adverbial function for SASSes in American Sign Language. 
example the handshape mentioned above - an open palm with all fingers stretched out (CL:flat-object): the dictionary entry with the default variant of the handshape in the headword contains five semantic fields, each of which represents a separate meaning (with their own semantic definition and examples of use). The first four explain the meaning and the use of the handshape within different classifier constructions, whereas the last field describes and exemplifies its use as a SASS.

Sometimes classifiers and specifiers undergo the process of lexicalisation. In that case, they are included in the dictionary and treated as lexemes. In these structures, the otherwise productive forms become 'frozen'. Their features (handshape, movement, place) no longer contribute morphological content to the given expression but bear only a phonological status (Sandler and Lillo-Martin, 2006). In ČZJ, we have, e.g., signs BOW ( $\approx$ ARCHERY) and TREE, which originated by lexicalising a classifier; or YOGHURT and OMELETTE, in which the motivating specifier can be recognised.

We are using a few additional criteria for distinguishing a productive classifier/SASS from a lexicalised form (other than the intuitions of native signers). First of all, we check for the meaning shift. The productive classifiers/SASSes are forms with an interpretation that is highly dependent on the preceding noun. After lexicalisation, the meaning of the form is fixed. That fact manifests itself in the redundancy of the nominal antecedent (which is obligatory for a productive classifier/SASS). And finally, the lexicalised forms originating from classifiers/SASSes acquire a mouthing that reflects the corresponding Czech translation. In contrast, a mouthing of Czech words is absent in productive classifiers/SASSes.

\section{MOUTH PATTERNS ACCOMPANYING SIGNS}

Non-manual components of signs defined as 'all linguistically significant elements that are not expressed by the hands' (Pfau and Quer, 2010) are equally as important for speech comprehension and production as the manual articulators. These components can take the form of head and body movements, facial expressions, or mouth patterns. In this section, we will focus on the last type and assess which mouth patterns should and should not be documented in a dictionary. 
Mouth patterns are commonly divided into mouth gestures and mouthings, differing in their relationship to the surrounding spoken language. Mouthings (or spoken components) are either influenced or directly derived from the corresponding word in the surrounding spoken language; they are silent articulations of the whole word or a part of it, usually its first syllable (Pfau and Quer, 2010). Mouthings are understood as cross-modal borrowings (Sandler and Lillo-Martin, 2006; Mareš, 2011). It is possible to observe a gradual change and adaptation to the 'host' language, a process typical for borrowings observed among spoken languages as well.

In our ČZJ data, we found two situations: (i) mouthings that are a conventional part of the sign and have no apparent effect on the interpretation; (ii) mouthings that distinguish among lexemes with otherwise identical manual components. The examples of the first type are the signs NAME, COUNT or WORK. These three examples illustrate that this type of mouthing is quite variable in its form. It varies among the silent articulation of the Czech equivalent, first syllables of the Czech equivalent, or a word semantically related to it: the manual articulation of NAME is accompanied by the mouthing of the Czech equivalent for name. COUNT appears with two initial syllables of the Czech equivalent for the verb to count and the non-manual part of WORK 'to work' is formed by the mouthing of the Czech word for the noun work, and not the verb. Moreover, the signers' preferences vary: some signers are more precise in mouthing of the Czech words than others. Hence, several variants mentioned above are acceptable for one lexeme, depending on the speaker.

The latter type of mouthing (mouthing that changes the meaning) can be found in the field of terminology. It represents one of the ČZJ strategies for expressing expert or technical terms. Remember, e.g., SUGAR and SACCHARIDE mentioned above in Section 2 - these signs share the manual part and differ by mouthing. From the semantic point of view, we understand these examples as a specification (or narrowing) of a general meaning. We observed that this strategy is not limited to the field of science, technology or other kinds of expertise. Consider the classifier construction for pouring little particles (CL:pour), articulated without mouthing, and the signs SALT, PEPPER and SPICE. All four share the same manual part, and the interpretation of the last three is determined by the mouthing of the Czech words for salt, pepper and spice. 
Let us now turn to the second type of mouth patterns. Mouth gestures (or oral components) are defined as 'all motions/positions of the mouth that are not derived from a spoken language and contribute to the speech structure' (e.g., Mareš, 2011, p. 8). They are therefore considered a native component of the given sign language.

Unlike mouthings (or at least the first type mentioned above), their form is relatively stable. Similarly to mouthings, we found two possible situations that contain the use of mouth gestures: (i) as an obligatory part of the sign (potentially a phoneme); or (ii) modifying the meaning of the sign. The first situation is exemplified by the signs HAVE/BE and WIND. Both of them are considered ungrammatical when pronounced without the mouth gesture. However, the mouth gesture does not associate with any particular semantics. On the other hand, cases of mouth gestures modifying the sign's meaning are visible in SMALL and RAIN-A-LOT. Morphologically speaking, the manual part of SMALL is the same as the manual part of the size and shape specifier expressing the size in general (SASS:size). The mouth gesture realized by the tip of the tongue coming out of the mouth modifies the sign's meaning by adding the semantic feature 'small'. Similarly, the manual part of RAIN-A-LOT shares the manual part with RAIN. The mouth gesture formed mainly by the puffy cheeks adds the aspectual modification (intensification). ${ }^{6}$

In order for mouth patterns to be included in Dictio, they need to satisfy two conditions: (i) they are obligatory for the given sign; and (ii) they do not introduce additional meaning in the sense that they do not modify the sign in terms of intensification, adjectival or adverbial modification, nor do they express the speaker's attitude (Mareš, 2011, p. 24; Pfau and Quer, 2010, p. 385). As a result, Dictio registers cases like NAME, COUNT, WORK, SUGAR, SACCHARIDE, HAVE/BE and WIND in separate dictionary entries. Examples like SMALL and RAIN-A-LOT are analysed as complex morphological structures (simultaneously articulated phrases) and do not appear in the headword of a dictionary entry. Any obligatory mouth patterns are given in the grammatical description for each meaning of the lexical entry (a corresponding Czech word for mouthings

6 In fact, the mouth gesture is just a part of the complex grammatical marker of intensification. The other obligatory component is the modification of the movement (fast repetition). 
and specialised symbols for different mouth gestures). In the case of a single sign (conveying a single meaning) with variable mouth patterns available, the headword is accompanied by the most neutral one. The other options are classified as variants of that sign and (in the optimal case) displayed on videos within the grammatical part of the entry.

\section{STRATEGIES OF SEMANTIC DEFINITIONS}

So far, we have discussed what kinds of lexemes are eligible to be listed in a dictionary, but let us now turn to each lexical entry structure with a particular focus on their definitions. The definition of a lexical entry is a crucial part of any monolingual dictionary. Thus, it is important to develop a firmly established method before beginning any lexicographic work and adhere to it throughout compiling a dictionary. This can be especially challenging in sign language dictionaries, where there is very little prior work to build on, and one may encounter several unprecedented issues. In Dictio, we face these challenges with the help of precisely outlined processes for forming each definition.

The Oxford Handbook of Lexicography contains an extensive chapter on the history and philosophical foundations of the concept of a dictionary definition (Hanks, 2016). However, with the lexicographic task at hand, we turned to the manuals describing current practice (e.g., Filipec, 1995) and we found two main strategies for defining the meaning - intensional and extensional definition. To define a lexeme intensionally means to specify necessary and sufficient conditions for using a given lexeme. Such intensional definition has the following structure: first, the closest general term, a hypernym, is posited to categorise the lexeme into a broader semantic class; the next step is to list necessary distinguishing properties in order to differentiate the lexeme from other elements of the same semantic class. This way, we delimit all potential occurrences while ruling out other cases. ${ }^{7}$ A nice example of the application of this general lexicographic strategy is the definition of the sign CD-ROM,

7 Since the key to the intensional definition is to capture the internal hierarchy of a given semantic area, the work of Půlpánová (2007) on ČZJ becomes useful. In her thesis, she investigated the signs used for categorisation in ČZJ. Under categorisation, she understands the expression of hyper-hyponymic relations in the lexicon. Such functional signs are, e.g., TYPE and GROUP in her elicited ČZJ expression ANIMAL TYPE GROUP HOME (in the meaning of pet). 
which is given here in glosses and can be seen under the link: CD-ROM ${ }_{a}$ IX-a CL:round-object SASS:thin $n_{b}$ IX-b SAVE DATA HOW CL:draw-circles ${ }_{a}$ HAVE/ $\mathrm{BE}_{\mathrm{a}}$ SASS:little-hills $\mathrm{s}_{\mathrm{a}}$ o 1001 .

Extensional definitions employ a different strategy. They specify an extension of a given lexeme, e.g., by naming a typical representative or several objects that are members of a specific set, requiring the reader to extract the properties common to all listed examples and compile the meaning of the lexeme from them. Such a definition can be accompanied by qualitative or circumstantial properties of a concept, e.g., size, colour, or application. An example is the semantic definition of the sign BLACK, which is given here in glosses and can be seen under the link: COLOUR IX-a LOOK-LIKE SUN GO-DOWN GET-DARK IX-b.

Between the two strategies, it is always preferred in our dictionary to use the intensional definition. However, in sporadic cases, the meaning can be determined extensionally or by combining the two, i.e., by specifying a superordinate concept followed by several examples of referents.

\section{MULTIPLE MEANINGS AND SEMANTIC RELATIONS}

In each lexical entry, the field of semantic relations includes both the intra-language relations (synonyms, antonyms), and the inter-language relations (translations). We will comment in detail on the first type, leaving the latter for Section 8. However, let us first consider the cases of polysemy.

In our dictionary, we follow the traditional practice of listing every meaning of a polysemous word under one lexical entry. These individual meanings differ, and therefore separate definitions, examples (and translations) are needed for them. ${ }^{8}$

In principle, we have encountered three types of situations: (i) a general term with multiple meanings (e.g., GERMAN, which may stand for the country or a citizen of the country); (ii) a technical term with different meanings for their respective semantic fields of use (e.g., the sign BASIS with three different

8 Currently, we are not able to differentiate between polysemy and homonymy. In the absence of an etymological dictionary of ČZJ, we register as polysemous all lexical units with more than one semantic definition. 
meanings - for the field of informatics, mathematics, and chemistry); and (iii) a sign with general and technical use. If the two forms are entirely identical - including the non-manual component - two meanings can be defined with the general one listed as first. However, more often, new mouthing is added during the creation of the technical term. In this case, we understand the non-manual component as a phoneme, and we register each sign under a separate entry. ${ }^{9}$

\subsection{Synonym-variant distinction}

In Dictio, we register synonyms (expressions with identical or nearly identical meanings) and variants (expressions with identical meanings wholly interchangeable with the headword). A question closely tied to both is how to distinguish them and classify them according to their formal and semantic relationship to a given lexical entry.

For audio-oral languages, a dictionary entry standardly contains the citation form of a lexeme and all the variants (Čermák, 1995), e.g., the gender variants in Czech: brambor 'potato-masculine' vs brambor-a 'potato-feminine'. However, two (or more) expressions of a different word-forming nature are not considered variants but synonyms (Filipec, 1995), e.g., the Czech pair: jazykověda 'linguistics' (Czech origin) vs lingvistika 'linguistics' (foreign origin).

What seems like a simple task for spoken languages (basically, common root signals variants, different roots - synonyms) becomes a challenge for sign languages because the discussion about the definition of morphemes and lexical roots is still open-ended (Zwitserlood, 2012). The lexicographic processing of the variants in sign languages has been addressed in Johnston and Schembri's (1999) canonical work for Australian Sign Language. However, the topic of synonyms is not elaborated.

In Dictio, a method has been developed (and is now being applied) to distinguish variants from synonyms in ČZJ (with possible extension to other sign languages). Our approach builds on the Sandler's (2006) phonological HandTier model and contributes a set of clear criteria for distinguishing variants from synonyms.

9 See Section 4 above, namely examples SUGAR and SACCHARIDE. 
The Hand-Tier model (depicted in Fig. 1) groups the phonological features of a given sign into categories (parameters) and subcategories, which are hierarchically organised and partly dependent on each other. The three main parameters are (i) handshape (or hand configuration); (ii) place of articulation; and (iii) movement. The handshape parameter can be further divided into smaller sets, e.g., orientation with features like [palm] and [wrist], which helps us record, simply put, which direction the signer's hand is facing. Within the handshape parameter, a subcategory registers the features of the non-dominant hand in symmetrical signs. The non-dominant hand either copies the dominant hand in its configuration or has one of the unmarked handshapes depicted in Fig. 2. Sandler (2006, p. 161) defines such handshapes as maximally distinct, the easiest to produce, the first to be acquired by children and the most frequent in sign language production. Note that the very same phonological subcategory (the non-dominant hand) can also be found in the place parameter. It is assigned in the case of two-handed non-symmetrical signs, within which the non-dominant hand fulfils the role of a place of articulation. Moving on to the next parameter, the place of articulation is defined by features conveying the main signing areas such as [head], [trunk] or the above-mentioned non-dominant hand. However, these can be in turn combined with the features from a subcategory called setting, e.g., [high], [low] or [proximal]. Moreover, the place category features can be divided into two sets corresponding to two locations of a sign (if applicable): an initial and a final position. In this case, it is also possible to link a certain position to a certain set of handshape features that describe the sign's form in that particular position. We have seen it, e.g., in the sign RECOMMEND, where the initial position is linked to a place of articulation on the cheek with the handshape of one extended finger, and the final position is articulated on the non-dominant hand with all the fingers extended. Finishing the description of the Hand-Tier model with the last main category of movement, we can see that it is unique with respect to its complexity and partition because there is no further division into subcategories within, there are only particular phonological features like [arc], [convex] or [rep] (= repetition).

Let us now turn back to the lexicographic task at hand: distinguishing variants from synonyms in ČZJ. Researchers have marked that a pair of signs is likely 


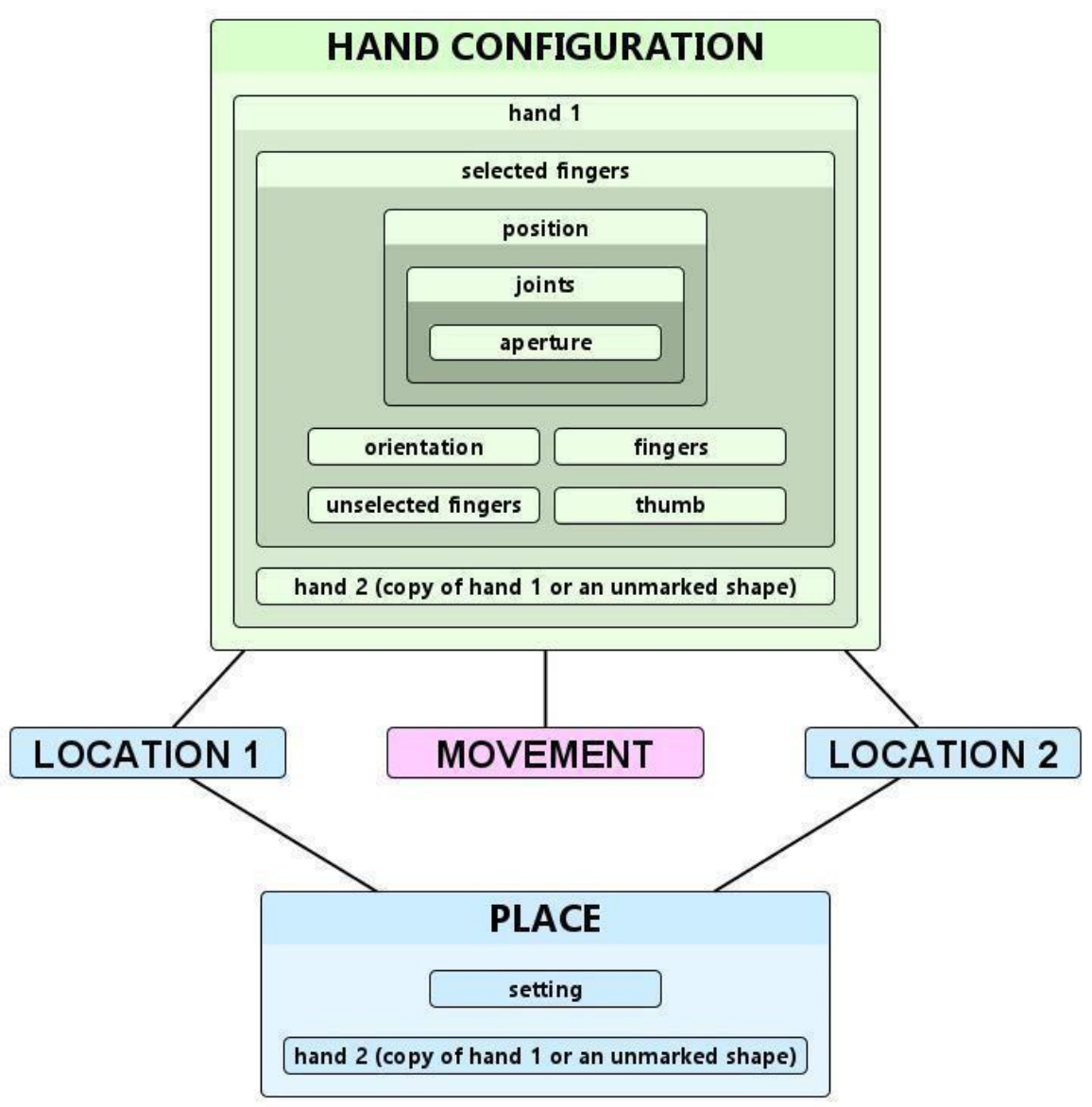

Figure 1: The Hand-Tier model.

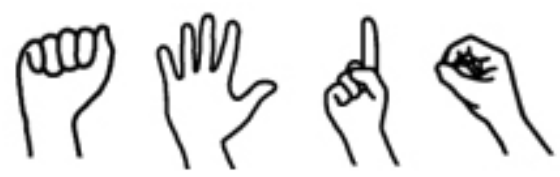

○) Vojtechovská Veronika, Vojtechovský Roman

Figure 2: Unmarked handshapes.

to be variants if they differ in just one parameter (Fenlon et al., 2015). However, the exact nature and characterization of the notion of one parameter was not specified and remained a subject of debate. This is where the Hand-Tier 
model can help determine what should be understood as a difference in one or more parameters, how to account for minimal pairs of signs and, consequently, which signs should be labelled as variants and which as synonyms. With this in mind, we propose to classify a pair of lexemes as variants in case their (possibly multiple) differing phonological features fall within only one of the three main parameters described above: handshape, place of articulation or movement. In other cases, we propose to classify them as synonyms. Let us look more closely at some specific classification issues and their possible solutions based on the Hand-Tier model.

Firstly, there are pairs with only a simple difference within one parameter. Variants altering within the handshape are exemplified by PRAGUE\#1 and PRAGUE\#2, whereas WHY\#1 and WHY\#2 demonstrate variants with a different movement. BROTHER-IN-LAW\#1 and BROTHER-IN-LAW\#2 differ in the place of articulation, but seemingly also in orientation. However, the orientation of the dominant hand is relative. It is always evaluated with respect to the place of articulation (in our example-pair, the upper part of the trunk and the non-dominant hand). Since the dominant hand and the place of articulation are in the same configuration in both signs (contact with the ulnar side of the hand), we analyze them as having the same features for orientation and differing only in the place of articulation.

Secondly, there are slightly more complicated cases to label, namely the pairs of signs with more than one difference in their respective phonological features. It still holds that as long as those differing features belong to a single main category, the signs are analyzed as variants. Take the ČZJ signs FOURTEEN\#1 and FOURTEEN\#2 as examples. At first glance, they differ in the orientation of the dominant hand (towards the addressee vs the signer), i.e. a feature within the main category of handshape, and in three aspects belonging to the main category of the place of articulation: (i) the handshape of the non-dominant hand, i.e. all vs one selected finger (in other words, a fist vs an extended thumb); (ii) the orientation of the non-dominant hand, i.e. the palm towards the addressee vs facing down; and (iii) the location, i.e. where exactly does the dominant hand touch the non-dominant one. If the two signs differed in their handshapes and their places of articulation, they would be classified as synonyms. Nevertheless, as we have seen before, the orientation is relative, 
so the seemingly different handshape features are predictable and follow from the location (iii). Therefore, at the phonological level, these two signs differ only within the features that belong to the one main category of the place of articulation, and as such are classified as variants.

Moving on to the higher level of contrast between two signs - from variants to synonyms - a straightforward example of synonymy is presented with the ČZJ signs KITCHEN\#1 and KITCHEN\#2. The lexemes differ in all three main categories, and there is no doubt that they do not share a morphological root. However, not all synonyms are so clear-cut. Examples similar to MAY\#1 and MAY\# 2 (which represent two forms from several variants and synonyms for May) are challenging, since they present two morphologically related forms. Nonetheless, given that they differ in two of the three main categories, namely handshape and movement, we conclude that they should be classified as synonyms. More complicated cases, such as MAY\#1 and MAY\#2, show that we are working with a scale rather than a binary distinction.

Building up from the least differences to the most, we have covered which sign pairs are considered variants and which ones are classified as synonyms. We will now focus on variants and present their different types. The primary distinction lies in their phonological status: a variant can be either phonetic or phonological. A phonetic variant in a sign language is produced slightly differently from the usual, conventional manner by an individual speaker. On the other hand, a difference found in a phonological variant is rooted more deeply, and the differing parameter can even play a role in a minimal pair. However, at this level of ČZJ exploration, there is no concrete methodology of distinguishing phonetic and phonological variants that could be used systematically in the dictionary. Therefore, we consult native signers of ČZJ and their intuitions to determine which differences between two signs are considered insignificant (= phonetic variants) and which ones are treated as using a different parameter within the sign (= phonological variants). Let us demonstrate with the following example. When it comes to the various number of repeating movements within a pair of signs, the pairs with several movements each (e.g., 2 and 3 repetitions, respectively, in signs CHRISTMAS\# 1 and CHRISTMAS\#2) were not judged as having a different phonological parameter, and are therefore registered as phonetic variants. On the other hand, when the contrast is 
between a single movement and several repeated ones (e.g., in signs WHY\#1 and WHY\#2), it is judged as a difference in the movement parameter of the sign, and as such it is a basis for classifying the two signs as phonological variants. This conclusion is also supported by other occurrences of this contrast and its undeniable phonological merit, e.g., in the minimal pair of MORNING and CLOTHES, where it is the only differing feature. Thus, we analyse the difference between one and several movements as the phonological feature [rep] and place it in the movement category. ${ }^{10}$

Once we have distinguished phonetic and phonological variants, let us look more closely at the latter ones. Phonological variants can be further divided into grammatical and stylistic ones. A grammatical variant is a lexeme that is freely interchangeable with the headword and does not add any extra information about the speaker. On the other hand, a stylistic variant adds such information about, e.g., social status, regional categorisation or a generation the speaker belongs to. Thus, grammatical and stylistic variants relate to the given lexeme in all its meanings, as opposed to synonyms, as was noted above, which are linked to the individual meanings within the entry.

\section{EXAMPLES OF USE}

In this section, we discuss examples, namely what kinds of expressions are appropriate for an example and what guidelines need to be followed when adding an example to an entry. In the absence of a ČZJ representative corpus, the examples of use are not elicited but created by the team of native signers, forming a small corpus by itself.

It is desirable to include at least one, but ideally, several examples are listed in each lexical entry, demonstrating the use of a given lemma in different communicative situations. An example could be an expression (two or more signs), a sentence, or an utterance (several sentences) illustrating the use of the lemma and/or its variants.

The fundamental idea of examples is to portray how lexemes are used in natural language. Therefore, it is not unusual to exemplify modification where

10 The feature of [rep] is mentioned in Sandler (2006), but its exact definition and place in the model have remained unclear. 
possible, such as numeral and classifier incorporation, the inflexion of directional verbs, aspectual modification, and plural and negated forms.

As an illustration of the strategy described above, consider two examples for MONTH. The first example contains a simple citation form, the second one a pluralised form with an incorporated numeral: (i) TOMORROW MONTH MAY (video under the link), (ii) SUMMER IN-THAT YEAR PERIOD ${ }_{a}$ HAVE $_{a}$ FOUR THREE-MONTH $++_{\mathrm{a}} 2^{\mathrm{ND}_{\mathrm{a}}}$ SEGMENT ${ }_{\mathrm{a}}$ IN-THAT JUNE $21^{\mathrm{TH}}$ UNTIL SEPTEMBER $22^{\mathrm{TH}}$ (video under the link).

\section{TRANSLATIONS}

The final section focuses on the bilingual part of our dictionary and notes some specific processes inherent to the bimodal character of Dictio. As was mentioned previously, Dictio was initially designed as a monolingual dictionary. However, as the project grew in size, more languages (spoken and sign) were added to the interface. Therefore, it became increasingly important to establish a coherent method of managing the ties among the languages and the specific entries with a translational counterpart. However, this effort still focused mostly on Czech and ČZJ, which retain their positions of the most documented languages within Dictio.

With a project of this size, naturally, there are many different translators among the contributors, each assigned their own respective (pair of) languages depending on their language training. Due to this dictionary's specific bimodal character, we are faced with several types of translation techniques based on the particular combination of languages in question - they can be both signed, both spoken, or it is a signed-spoken pair. In this paper, we will examine some specifics of the last type.

First let us outline two general principles concerning the translation process, which have been applied throughout the dictionary. Firstly, when linking two corresponding lexemes from different languages via translation, it is essential to target the specific meanings (if there are several to choose from) and not equate the two dictionary entries. It is a common practice that ensures, e.g., that the English polysemous word bed is linked to the Czech lexeme postel only in the meaning of 'a piece of furniture for sleeping' and not 'the bottom 
of the sea, lake or river', which is conveyed by the Czech lexeme dno. Secondly, while finding the corresponding equivalent (sign or spoken), the translators never rely only on their knowledge of the languages they work with. That means, when they look, e.g., for the Czech translation of the English lexeme bed, they never work only with the headword in the dictionary entry. They are always guided by the semantic definition(s) and assign the translation that corresponds to the definition. That is why the definitions need to be construed clearly and unambiguously (and when a certain definition lacks these qualities, it needs to be revised). However, even clear and unambiguous definitions can have different translations, which are often linked among each other as synonyms.

Let us now focus in more detail on the translation process employed between a signed and a spoken language, demonstrated by some tricky examples from Czech and ČZJ. It proved useful to provide the editors with the following guidelines concerning the use of mouthing. In ČZJ, there are several situations where only the mouth pattern differentiates between several signs with identical manual components. It is important to be guided by the mouth pattern while translating these signs into a spoken language. As we have shown before (in Section 4), this is useful especially when linking a set of morphologically and semantically related ČZJ signs like SALT, PEPPER and SPICE to their respective Czech translations. Translators tend to understand such sets as one sign language lexeme with several options of mouthing. However, in Dictio, each mouthing determines one dictionary entry. Hence the Czech translations should be distributed accordingly.

At the same time, relying solely on the non-manual component of the sign will not suffice and can be misleading. In some cases, the mouthing and the sign translation differ, although they can be related. Take BECAUSE in ČZJ as an example: the sign has a mandatory mouthing of the Czech word dưvod 'a reason'. However, the entry contains two meanings, one of them is translated into Czech as divvod 'a reason' and the other as protože 'because'. Note that even in the second meaning, the sign is still accompanied by the silent articulation of the Czech word diovod 'a reason'.

Until now, we talked about cases that represent linking two dictionary entries, although at the level of individual meaning: for example, the first meaning 
of ČZJ SALT is translated as Czech sůl in its first meaning ('white material, in powder or chunks, used to prepare dishes'). However, some entries need a translation that does not qualify as a dictionary entry. Below, we describe two types of situations with one thing in common: the ČZJ lexeme fulfils the requirement for a dictionary entry (see Section 2 above), but the corresponding Czech translation does not.

The first type of examples can be illustrated by the signs with numeral incorporation, like LAST-WEEK. Morphologically speaking, the sign consists of a handshape for the numeral SEVEN, and a movement of the sign PAST. Compositionally, we could read the meaning as 'seven days ago'. However, the Czech translation (minuly týden 'last week') is a common noun phrase with an adjective modifier (a collocation, from the lexicographic point of view). In general, those are the situations, in which the signed member of the pair is a single lexical unit (and as such is recorded in the dictionary), while the translation into the spoken language is a common syntactic phrase (which is not recorded in the dictionary). Apart from numeral incorporation, we might name examples like CHAINSAW (motorová pila in Czech) or AT-NOON ( $v$ poledne in Czech).

The second type of examples is represented with the ČZJ sign NOT-HAVE/ $\mathrm{BE}$, a suppletive negative form for HAVE/BE. While the Czech translation for the latter is listed as a dictionary entry (mít 'to have', být 'to be'), the irregular ČZJ form is translated by a regular Czech form (nemít 'not to have' and nebýt 'not to be'). Naturally, the regular negative forms of verbs are not listed as dictionary entries. They are produced by a regular word-forming process of adding a negative prefix ne- 'not'. The technical solution in Dictio is to provide the Czech translation in the form of a plain text, that means, without an interactive link to a corresponding semantic equivalent in the Czech part of the dictionary.

\section{CONCLUSION}

Dictio is a work in progress, similar to any other dictionary trying to capture and describe natural language. However, even now, in its developmental stages, it already serves multiple functions. Dictio has been used in ČZJ courses, linguistic education, and by translators, providing valuable examples of signs 
and their categorisation. Moreover, it represents the most extensive ČZJ material collection to date, containing both the individual signs and the utterances elicited from native signers.

This paper presented several methods implemented during the creation of the first Czech Sign Language online dictionary. We introduced the formal and semantic criteria for lemmatisation and classified the headwords into four groups: a simple lexeme, a compound, a derivative, and a set phrase. We established the place of the classifiers and the size and shape specifiers in the dictionary by applying our criteria consistently: once a stable form can be associated with a conventional meaning, it qualifies for a dictionary entry. We argued for an independent category of size and shape specifiers, apart from the classifiers, by showing their different grammatical properties. We explored several functions of mouthing and mouth gestures and proposed the criteria for this type of non-manuals in the headword: obligatoriness and absence of a grammatical or pragmatic modification function. We introduced the two types of semantic definitions (intensional and extensional) and specified the appropriate use for each of them. We discussed multiple meanings and semantic relations and showed the complexity of variant-synonym classification in sign languages. We elaborated the minimal difference requirement for the variant pairs using the phonological Hand-Tier model. We offered a guideline to create sound examples of use by highlighting the variability of the headword. Finally, we commented on translating between spoken and sign languages and discussed various types of sign-spoken lexeme pairs resulting from this process.

Dictio poses many lexicographic challenges, and solving them brings us closer to understanding the nature of Czech Sign Language (among others) and its phenomena. One of the most challenging topics that will be addressed in the near future is the assignment of lexical categories to the signs.

\section{Acknowledgments}

We would like to acknowledge Dictio for providing us with all video examples given in the text and Appendix. 


\section{REFERENCES}

Battison, R. (1978). Lexical borrowing in American sign language. Linstok Press, Silver Spring.

Čermák, F. (1995). Paradigmatika a syntagmatika slovníku: možnosti a výhledy. In F. Čermák \& R. Blatná (Eds.), Manuál lexikografie. Jinoča$n y: H \& H, 1,90-115$.

Dictio: Multilingual Online Dictionary. (2020). Brno: Masaryk University. Retrieved from https://www.dictio.info

Le Dico Elix - Le dictionnaire vivant en langue des signes française (LSF). (2020). Retrieved from https://dico.elix-lsf.fr/

e-LIS: Electronic bilingual dictionary Italian Sign Language - Italian. (2020). Retrieved from http://elis.eurac.edu/index_en.html

Fenlon, J., Cormier, K., \& Schembri, A. (2015). Building BSL SignBank: The lemma dilemma revisited. International Journal of Lexicography, 28(2), 169-206. Retrieved from https://www.researchgate.net/ publication/276164152_Building_BSL_SignBank_The_lemma_dilemma_revisited

Filipec, J. (1995). Teorie a praxe jednojazyčného slovníku výkladového. In: F. Čermák in R. Blatná (Eds.), Manuál lexikografie. Jinočany: $H \& H, 1$, 14-49.

Hanks, P. (2016). Definition. In P. Durkin (Ed.), The Oxford handbook of lexicography. doi: 10.1093/oxfordhb/9780199691630.001.0001

Johnston, T., \& Schembri, A. C. (1999). On defining lexeme in a signed language. Sign language \& linguistics, 2(2), 115-185.

Kristoffersen, J. H., \& Troelsgård, T. (2012). The electronic lexicographical treatment of sign languages: The Danish Sign Language Dictionary. In S. Granger in M. Paquot (Eds.), Electronic Lexicography. Oxford University Press.

Langer, J., Ptáček, V., \& Dvořák, K. (2005). Znaková zásoba českého znakového jazyka k rozšiřujícímu studiu surdopedie se zaměřením na znakový jazyk (I, II). Olomouc: Palacký University.

Langer, J., Ptáček, V., \& Dvořák, K. (2005a). Znaková zásoba českého znakového jazyka k rozšiřujícímu studiu surdopedie se zaměřením na znakový jazyk (III, IV). Olomouc: Palacký University. 
Langer, J., \& Kukolová, P. (2008). Slovník vybraných pojmů znakového jazyka pro oblast biologie člověka a zdravovědy. Praha: Fortuna.

Mandel, M. (1981). Phonotactics and morphophonology in American Sign Language. PhD dissertation, University of California. Retrieved from https://escholarship.org/content/qt9ovij5kx/qt9ovij5kx.pdf

Mareš, J. (2011). Orální komponenty v českém znakovém jazyce. Bc. thesis, Charles University. Retrieved from http://hdl.handle.net/20.500.11956/50230

McKee, R., Vale, M., Hanks, P., \& de Schryver, G. M. (2017). Sign language lexicography. International Handbook of Modern Lexis and Lexicography. Berlin/Heidelberg: Springer. Retrieved from https://www.researchgate. net/publication/319881867

Mladová, P. (2009). Kompozita v českém znakovém jazyce. Bc. thesis, Charles University.

Pfau, R., \& Quer, J. (2010). Nonmanuals: their grammatical and prosodic roles. In D. Brentari (Ed.), Sign Languages (pp. 381-402). New York: Cambridge University Press.

Potměšil, M. (2002). Všeobecný slovník českého znakového jazyka, A-N. Praha: Fortuna.

Potměšil, M. (2004). Všeobecný slovník českého znakového jazyka, O-Ž. Praha: Fortuna.

Potměšil, M. (2004a). Všeobecný slovník českého znakového jazyka, O-Ž doplněk. Praha: Fortuna.

Půlpánová, L. (2007). Kategorizace v českém znakovém jazyce. Mgr. thesis, Charles University. Retrieved from http://hdl.handle.net/20.500.11956/13566

Quer, J., Cecchetto, C., \& Donati, C. (2017). SignGram Blueprint: A guide to sign language grammar writing (p. 896). Berlin: De Gruyter. Retrieved from https://www.researchgate.net/publication/321962244_SignGram_Blueprint_A_ Guide_to_Sign_Language_Grammar_Writing

Sandler, W. (1989). Phonological Representation of the Sign: Linearity and Non-linearity in American Sign Language. Dordrecht: Foris.

Sandler, W. (2006). Phonology. In W. Sandler \& D. Lillo-Martin (Eds.), Sign Language and Linguistic Universals, 1, 111-278. New York: Cambridge University Press. 
Sandler, W. (2006). Entering the lexicon: lexicalization, backformation and cross-modal borrowing. In W. Sandler \& D. Lillo-Martin (Eds.), Sign Language and Linguistic Universals, 1, 94-107. New York: Cambridge University Press.

Sandler, W., \& Lillo-Martin, D. (2006). Classifier constructions. In W. Sandler \& D. Lillo-Martin (Eds.), Sign Language and Linguistic Universals, 1, 76-93. New York: Cambridge University Press.

Stokoe, W. C. (1960/2005). Sign language structure: An outline of the visual communication systems of the American deaf. Journal of Deaf Studies and Deaf Education, 10(1), 3-37.

Supalla, T. (1986). The classifier system in American sign language. Noun classes and categorization, 7, 181-214.

Zeshan, U. (2002). Towards a notion of 'word' in sign languages (pp. 153179). Cambridge: Cambridge University Press.

Zeshan, U. (2004). Interrogative and Negative Construction in Sign Languages. Language, $80(1), 7-39$.

Zwitserlood, I. (2010). Sign Language Lexicography in the Early 21st Century and a Recently Published Dictionary of Sign Language of the Netherlands. International Journal of Lexicography, 23(4), 443-476.

Zwitserlood, I. (2012). Classifiers. In R. Pfau, M. Steinbach \& B. Woll (Eds.), Sign Language. An International Handbook (pp. 158-186). Berlin/ Boston: De Gruyter Mouton. Retrieved from https://www.researchgate.net/ publication/291214641_Classifiers 


\section{LEKSIKOGRAFIJA ZNAKOVNEGA JEZIKA: ŠTUDIJA PRIMERA SPLETNEGA SLOVARJA}

V prispevku so predstavljeni tako nekateri izzivi leksikografije znakovnih jezikov kot rešitve za te izzive, ki so bile rabljene v prvem spletnem slovarju češkega znakovnega jezika (ČZJ), ki je del platforme Dictio, razvite na Masarykovi univerzi v Brnu na Češkem. V prvem razdelku prispevka je predstavljena platformo Dictio, govorjeni in znakovni jeziki, ki so vključeni v to bazo podatkov, število javnih vnosov in temelji te baze. Kratko je povzeto metodološko ozadje projekta, izpostavljena pa je edinstvena lastnost slovarja - pomenske definicije in primeri rabe v češkem znakovnem jeziku. V drugem razdelku so kriteriji lematizacije aplicirani na gradivo iz znakovnega jezika, definirani pa so tudi jezikoslovni kriteriji za slovarska gesla. Predstavljena je tipologija kandidatov za slovarski vnos, te tudi kratko komentiramo. Gre za preproste lekseme, zloženke, izpeljanke, zveze, deiktične izraze, opise in kolokacije. S pomočjo množice pomenskih in morfoloških kriterijev identificiramo prve štiri kot izraze, ki so lahko vključeni v slovar.V tretjem razdelku pojasnimo leksikografski proces dveh prominentnih leksikalnih kategorij znakovnega jezika, tj. klasifikatorjev in določil velikosti in oblike. Ohranimo standardni klasifikaciji klasifikatorjev (celotna entiteta ali klasifikator držanja) ter določil velikosti in oblike (statična in pomična določila) ter podamo argumente za ločevanje kategorij klasifikatorjev od kategorij določil. V četrtem razdelku opišemo dva tipa prvin, ki morata biti poleg kretenj odražena v slovarju: oralizacija in premikanje ust. S pomočjo primerov pojasnimo njuno funkcijo ter pokažemo, da so v slovarju zabeležene le tiste prvine, ki so obvezne in ne delujejo kot modifikatorji. V petem razdelku pojasnimo koncept dveh tipov pomenskih definicij: intenzijske in ekstenzijske definicije. Podamo primere obeh in prikažemo argumente, ki govorijo v prid prvemu tipu definicij. V razdelku 6 podamo prve primere večpomenskosti. Predstavimo tipologijo večpomenskih leksemov v ČZJ in pojasnimo njihovo organizacijo v slovarskem geslu. Nato se posvetimo k sopomenskosti. Pojasnimo razliko med sopomenko in različico v znakovnem jeziku ter predstavimo natančno metodo za razlikovanje med tema skupinama, pri čemer gradimo na modelu »hand-tier « (Sandler, 2006). V sedmem razdelku podamo preprosta navodila za oblikovanje pravih primerov rabe v znakovnem jeziku. Razdelek 8 je namenjen procesu prevajanja, in sicer prevajanja iz znakovnega $v$ govorjeni jezik. Razpravljamo o pomenu pomenskih definicij in prvin, ki niso kretnje. Kratko komentiramo tehnične rešitve za asimetrične pare, $\mathrm{v}$ katerih eden od delov prevoda ni naveden kot 
slovarsko geslo. Prispevek zaključimos povzetkom vlog, ki jih v skupnosti uporabnikov češkega znakovnega jezika igra platforma Dictio.

Ključne besede: znakovni jezik, leksikografija, slovar, metodologija

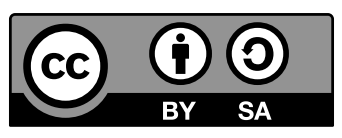

To delo je ponujeno pod licenco Creative Commons: Priznanje avtorstva-Deljenje pod enakimi pogoji 4.o Mednarodna. / This work is licensed under the Creative Commons Attribution-ShareAlike 4.0 International.

https://creativecommons.org/licenses/by-sa/4.o/ 


\section{APPENDIX 1: LIST OF MENTIONED DICTIO ENTRIES}

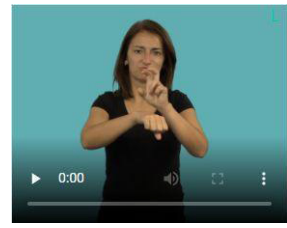

ANIMAL

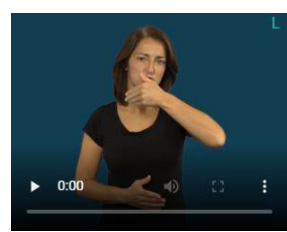

BLACK

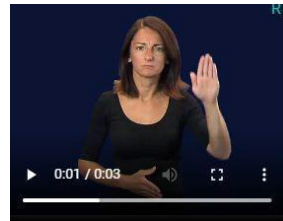

CL:flat-object

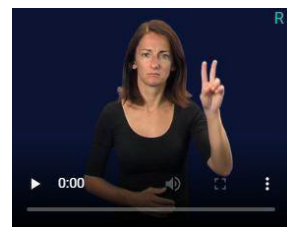

CL:two-legs

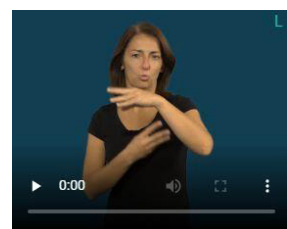

FEBRUARY

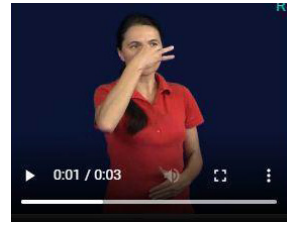

GERMAN/GERMANY

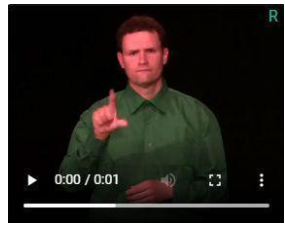

AT-NOON

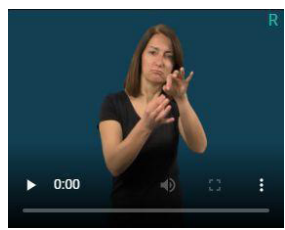

BOW/ARCHERY

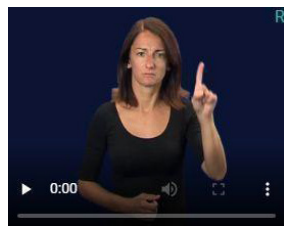

CL:person

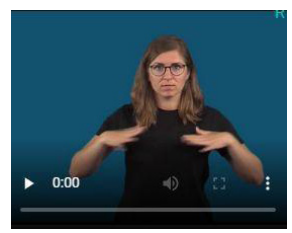

CLOTHES

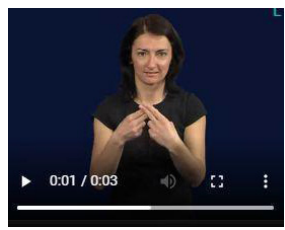

FLOWER $^{\wedge}$ SPRING

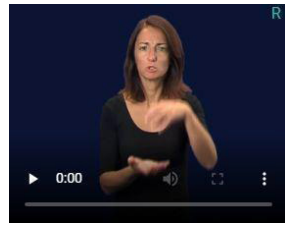

GROUP

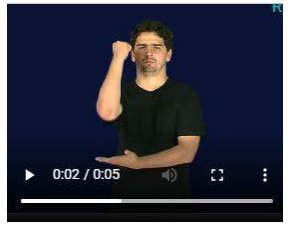

BASIS

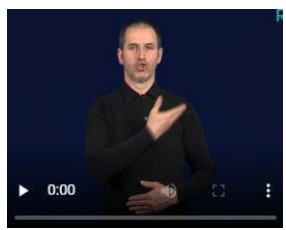

BROTHER-IN-LAW\# 1

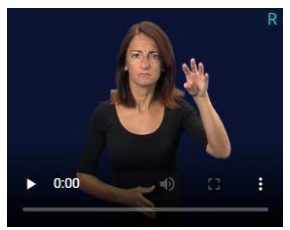

CL:round-object

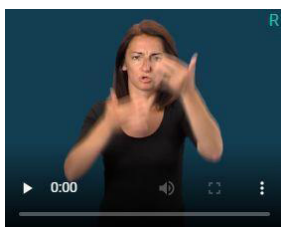

COUNT

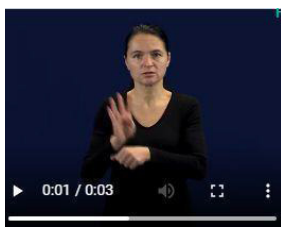

FOURTEEN\#1

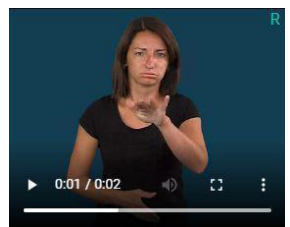

HAVE/BE

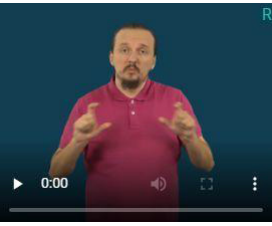

BECAUSE

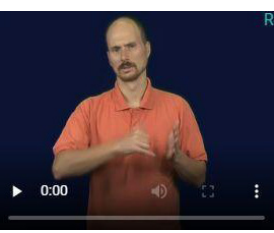

CD-ROM

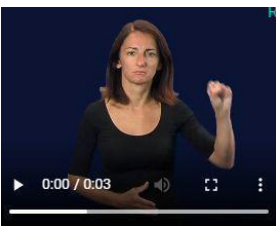

CL:thin-object

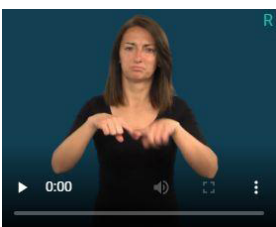

DEFECT

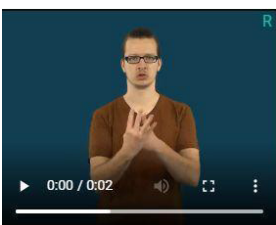

FOURTEEN\#2

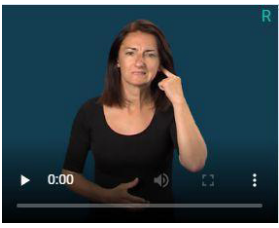

HEAR 


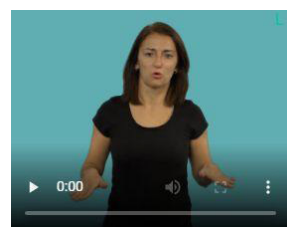

HOME

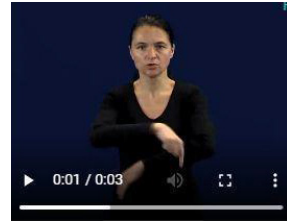

KITCHEN\#1

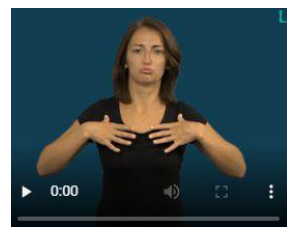

MORNING

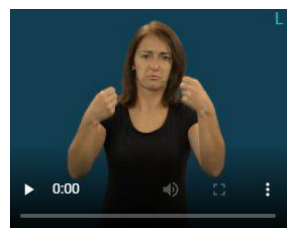

PRAGUE\#1

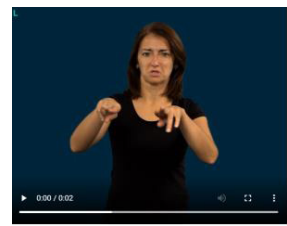

RETURN

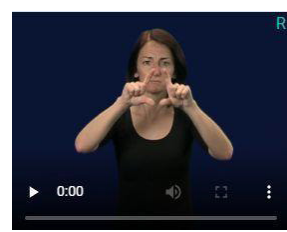

SASS:rectangle

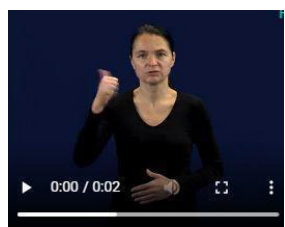

HOUR

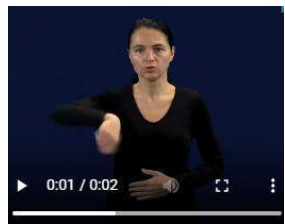

KITCHEN\#2

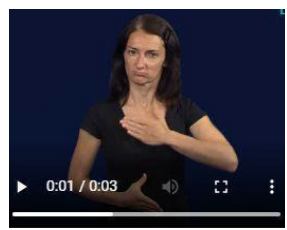

MY

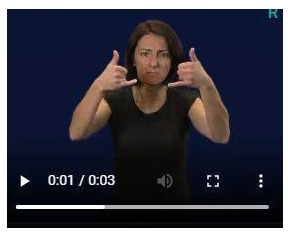

PRAGUE\#2

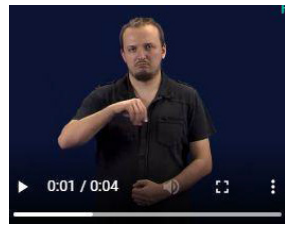

SALT/PEPPER/SPICE

/CL:pour

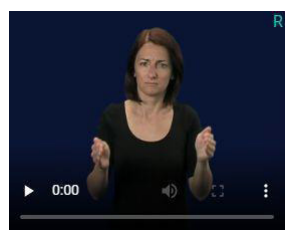

SASS:size

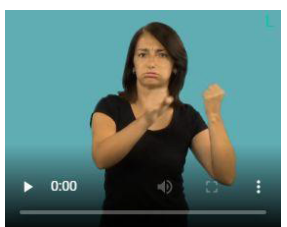

CHAINSAW

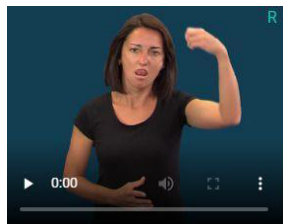

LAMP

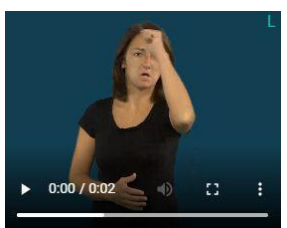

NAME

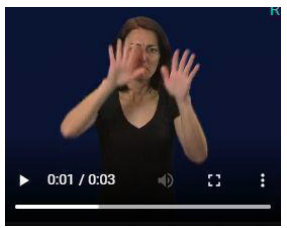

RAIN

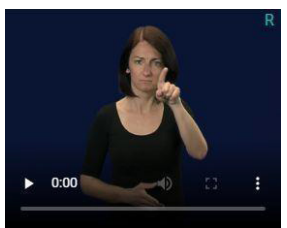

SASS:circle

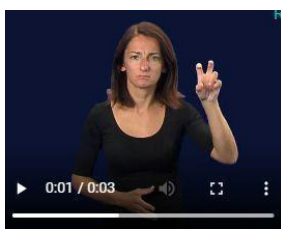

SASS:three-rows

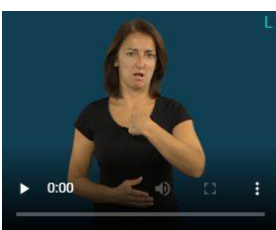

I

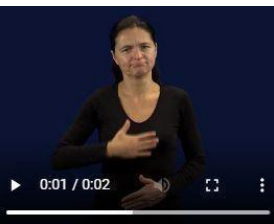

LIKE

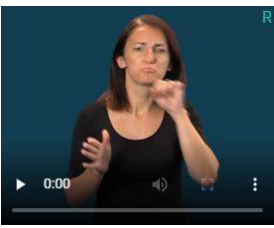

POST-OFFICE

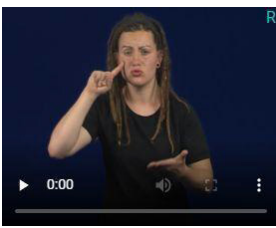

RECOMMEND

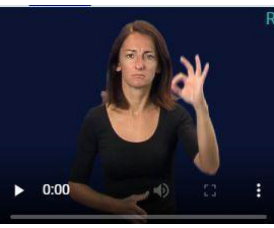

SASS:dot

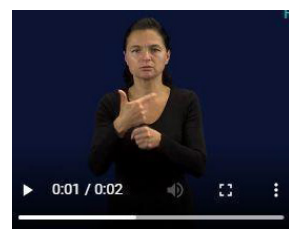

SUGAR/SACCHARIDE 


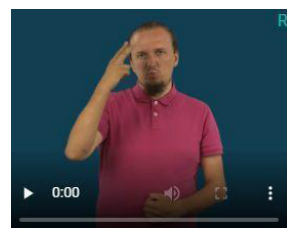

SUN^GLASSES

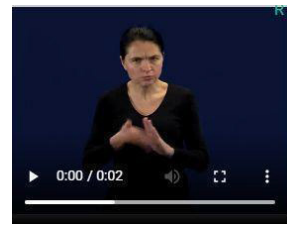

WHY\#1

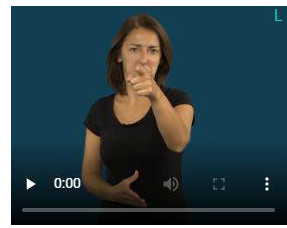

YOU

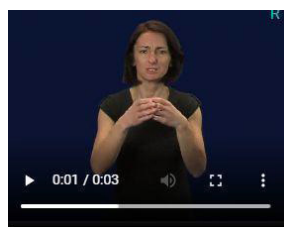

TREE

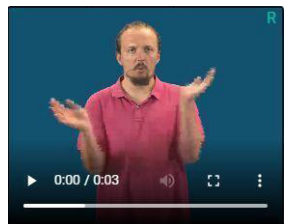

WIND

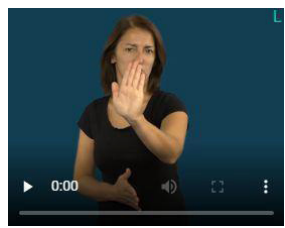

YOUR

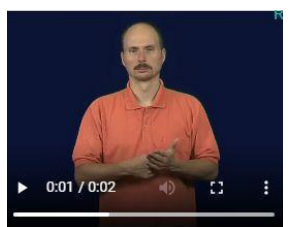

TYPE

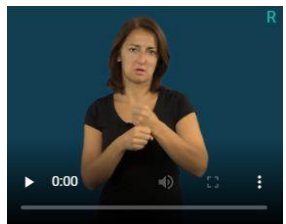

WORK

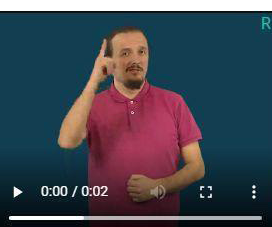

UNIVERSITY

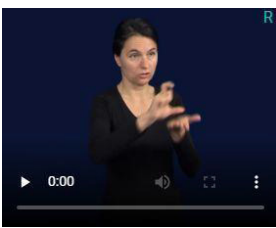

YOGHURT

\section{APPENDIX 2: NOTATIONAL CONVENTIONS}

SIGN

SIGN $_{\mathrm{a}}$

${ }_{\mathrm{a}} \mathrm{SIGN}_{\mathrm{b}}$

INDEX-a/IX-a

SIGN-SIGN

S-I-G-N

$\mathrm{SIGN}^{\wedge} \mathrm{SIGN}$

SIGN++

SIGN\#1

CL:c ' $\mathrm{x}$ '

SASS:sass ' $x$ '
A gloss of a lexical sign is given in small caps.

A letter subscript indicates the expression is signed in locus $a$ (= a position in the signing space). Locus names $(a, b, c . .$.$) are assigned from the signer's$ right to left.

Two letter subscripts indicate a sign signed from locus $a$ to locus $b$. Loci 1 and 2 correspond to the position of the signer and addressee, respectively.

A pointing sign towards the locus $a$.

Two hyphenated expressions indicate that more than one word is required to gloss a single sign.

Small caps letters separated by hyphens indicate fingerspelled words.

Two signs joined by a caret indicate compounding or a sign plus affix combination.

Two pluses indicate sign reduplication.

A number after a hashtag indicates a variant of a sign.

A classifier is indicated using CL, followed by its specification/description, and its meaning in single quotes.

A shape and size specifier is indicated using SASS, followed by its specification/ description, and its meaning in single quotes. 